$4-15-2019$

\title{
Under-reaction in the Sovereign CDS Market
}

\author{
Yaqing Xiao \\ Rutgers University \\ Hongjun Yan \\ DePaul University \\ Jinfan Zhang \\ International Monetary Fund
}

Follow this and additional works at: https://via.library.depaul.edu/buspubs

Part of the Business Commons

\section{Recommended Citation}

Xiao, Yaqing and Yan, Hongjun and Zhang, Jinfan, Under-reaction in the Sovereign CDS Market (April 15, 2019). Available at SSRN: https://ssrn.com/abstract=3372551 or http://dx.doi.org/10.2139/ssrn.3372551

This Article is brought to you for free and open access by the Driehaus College of Business at Digital Commons@DePaul. It has been accepted for inclusion in Publications - Dreihaus College of Business by an authorized administrator of Digital Commons@DePaul. For more information, please contact digitalservices@depaul.edu. 


\title{
Under-reaction in the Sovereign CDS Market ${ }^{*}$
}

\author{
Yaqing Xiao \\ Capital University of Economics and Business \\ yaqing.xiao@outlook.com \\ Hongjun Yan \\ DePaul University \\ hongjun.yan.2011@gmail.com. \\ Jinfan Zhang \\ Chinese University of Hong Kong (Shenzhen) \\ zhangjinfan@cuhk.edu.cn
}

This Draft: April 15, 2019

\footnotetext{
* We thank the participants at the CICF, DePaul University, Tsinghua Finance Workshop, University of Cincinnati, University of Illinois at Chicago, University of Iowa for helpful comments. The latest version of this paper is available at https://sites.google.com/site/hongjunyanhomepage/. Please address all correspondence to Hongjun Yan.
} 


\title{
Under-reaction in the Sovereign CDS Market
}

\begin{abstract}
The sovereign CDS market has been growing rapidly in recent years, with a gross notional amount of around 2 trillion dollars in 2015. We document a strong momentum effect in this market. Its unique feature is that this momentum strategy returns are positively skewed and higher during recessions. Hence, this effect cannot be attributed to momentum crash risk or exposure to business cycles. Our evidence is consistent with the interpretation that the effect is due to investors' initial underreaction to sovereign credit information followed by corrections, especially during public announcements of credit rating or outlook changes of the underlying countries.
\end{abstract}

JEL Classification Numbers: G12.

Keywords: Underreaction, Macro information, Sovereign CDS, predictability, limits to arbitrage. 


\section{Introduction}

A sovereign CDS contract allows market participants to purchase or sell protection against the default risk of a sovereign government. The sovereign CDS market has been growing rapidly in the past decade. According to the Depository Trust \& Clearing Corporation, the aggregate notional amount of sovereign CDS contracts is around \$2 trillion in 2015. Our paper examines the momentum strategy in this large and fast-growing market, and its potential causes.

Given the extensive momentum literature since Jegadeesh and Titman (1993), why is it worthwhile examining this phenomenon in yet another market? In addition to the fact that the sovereign CDS market is enormous and fast growing, this market has two unique features that separate our study from the rest of the literature. First, the investors in this market are almost exclusively sophisticated financial institutions. Hence, one might expect that these institutions are less subject to behavioral biases, since it is not obvious whether individual biases would manifest themselves in the decision making of sophisticated institutions. Many prior studies mostly focus on stock markets, where naïve investors are expected to be more prevalent. ${ }^{1}$ Even in derivative markets and currency markets, retail investors can be quite active. Hence, by focusing on a market with sophisticated institutions, our paper sheds new light on the momentum literature. Indeed, as explained in detail later, the sovereign CDS momentum returns display several unique features relative to all those documented in other markets.

Second, the information structure in the sovereign CDS market helps shed light on the mechanism behind the momentum effect in this market. As summarized in Barberis and Thaler (2003), behavioral models of momentum can be classified along two dimensions: the information structure and the cause of momentum. Along the information structure dimension: a

\footnotetext{
${ }^{1}$ According French (2008), direct holdings account for half of the U.S. stock market in the 1980s. Even though direct holdings have been declining, it still accounts for more than 20\% in 2007.
} 
key distinction is whether the information in the model is public or private. In the sovereign CDS market, the main information is about macro-level variables (e.g., the creditworthiness of sovereign governments). Hence, most of the information is arguably publicly available. Given the sophistication of the investors in this market, it is perhaps reasonable to expect most of them to have the capacity to process the information. Hence, models based on public information (e.g., Barberis, Shleifer, and Vishny (1998) and De Long et al. (1990)) perhaps are more suitable for explaining the momentum phenomenon in the sovereign CDS market. Moreover, as explained in detail later, our evidence on the properties of the momentum returns can help further distinguish models along the second dimension (i.e., the cause of momentum) and shed further light on the mechanism behind the momentum effect in the sovereign CDS market.

We obtain sovereign CDS market data on 91 countries during 2001 to 2015. Following Berndt and Obreja (2010), we construct the monthly sovereign "CDS returns,” which effectively measure the sovereign CDS market implied excess returns from the exposure to the underlying sovereign credit risk. Our main findings are the following.

First, we document a strong momentum effect in the sovereign CDS market. Specifically, we sort countries into 5 quintiles based on their past 3-month sovereign CDS returns. Quintile-1 countries have the highest sovereign CDS returns, i.e., their credit worthiness improved the most according to the sovereign CDS market, while quintile-5 countries have the lowest sovereign CDS returns. We find strong evidence that the sovereign CDS of quintile- 1 countries continue to outperform that of quintile-5 countries. In particular, we form an equal-weighted portfolio of sovereign CDS for each quintile. During the first month after the sorting, the quintile-1 portfolio outperforms the quintile- 5 portfolio by $0.58 \%$ per month ( $t=3.18$ ). After accounting for the exposures to the sovereign CDS market return factor and the global value and momentum factors 
in Asness, Moskowitz and Pederson (2013), the long-short strategy return is still $0.55 \%$ per month $(t=3.20)$.

One might be concerned that the above momentum returns are driven mostly by CDS contracts that are on small economies and not actively traded. Without detailed data on the total size of the outstanding sovereign CDS contracts for each country, however, we form GDPweighted sovereign CDS portfolios to give lower weights to smaller economies and the resulting momentum returns remain very similar. We also find that the sovereign CDS momentum effect is robust for various sorting periods and holding periods. For example, for the one-month holding period, the long-short portfolio return is $0.46 \%$ per month $(t=2.67)$ and $0.45 \%$ per month $(t=2.81)$ when the sorting period is one month and six months, respectively. The long-short return only gradually becomes insignificant when the holding period becomes longer than 6 months.

Second, in contrast to the evidence on the momentum effect in other markets, sovereign CDS momentum returns are positively skewed and higher during recessions. For instance, for the strategy with a three-month sorting period and a one-month holding period, the skewness of the long-short return is 2.94 ( $t=2.92)$. Moreover, the average return during the two recessions in our sample is $1.43 \%$ per month, while that for the non-recession period is only $0.41 \%$ per month, with the $t$-statistic for the return difference being 2.24. Hence, the sovereign CDS momentum returns cannot be attributed to momentum crash risk (Daniel and Moskowitz (2016)) or the exposure to the business cycle (Asness, Frazzini, Israel, Moskowitz (2014)).

Third, consistent with the interpretation that the sovereign CDS momentum is due to underreaction, the average momentum strategy return increases with the holding period, and that there appears to be no reversal. For instance, the cumulative alpha is $0.55 \%(t=3.20), 1.11 \%$ $(t=3.04)$, and $1.50 \%(t=2.47)$ if the holding period is 1,3 , and 6 months, respectively. The 
cumulative alpha gradually loses statistical significance when the holding period further increases. This evidence is consistent with the interpretation of initial under-reaction followed by correction. There is no evidence of overreaction.

Fourth, the timing of the sovereign CDS momentum returns is consistent with the interpretation that the sovereign CDS market underreacts to the information on the creditworthiness of the underlying countries and the momentum strategy generates profits when this undereraction is eventually corrected. When should the correction happen? A natural conjecture is perhaps when the sovereign credit information becomes public, i.e., when credit rating or outlook changes are announced. This conjecture implies that the sovereign CDS momentum strategy should be more profitable around the time when credit rating agencies, such as the Standard \& Poor's, announce changes in credit ratings or outlooks. Indeed, our estimates show that the profit of the sovereign CDS momentum strategy is accrued mostly during those announcement months. We further separately analyze the profit from the long and short legs of the momentum strategy, and find that the momentum profit is from both legs. The profit from the short leg (i.e., buying protections) is concentrated almost entirely during announcement months. In contrast, the profit from the long leg is distributed more evenly across time. That is, while good news (i.e., upgrade in outlook or rating) tends to be incorporated into sovereign CDS spreads gradually, bad news tends to be incorporated in sovereign CDS spreads more abruptly around announcements.

Fifth, we decompose sovereign CDS returns into a global component and a countryspecific component, and find that both components contribute to the momentum returns. This test is motivated by the evidence in Xiao, Yan, and Zhang (2018) that sovereign CDS returns can predict future stock index returns, sovereign bond yields, as well real macroeconomic variables 
such as GDP and PMI, and that the predictive power is almost entirely from the global, rather than country-specific, component of sovereign CDS returns. However, our evidence suggests that both components have predictive power for future sovereign CDS returns in the crosssection, and hence contribute to the momentum effect.

Finally, we follow Moskowitz, Ooi, and Pedersen (2012) to analyze the time-series momentum in the sovereign CDS market. We find significant time-series momentum returns for various sorting and holding periods, although their economic magnitude is much smaller relative to that of cross-sectional momentum strategies. For example, for a 3-month sorting period and a 1 -month holding period, the time series momentum return is $0.19 \%$ per month $(t=2.93)$, which is less than one third of the return from a similar cross-sectional momentum strategy.

As pointed in Barberis and Thaler (2003), behavioral models of momentum can be classified by the two causes of momentum: initial under-reaction followed by correction and initial overreaction followed by even more overreaction. Those models can also be classified by the two information structure: models with public information and models with private information. Hence, one can classify the four major behavioral models as follows: Barberis, Shleifer, and Vishny (1998) is based on public information and underreaction, while De Long et al. (1990) is based on public information and overreaction. Both Hong and Stein (1999) and Daniel, Hirshleifer, and Subrahmanyan (1998) are based on private information. The former is based on underreaction while that latter overreaction. As argued earlier, public information likely plays a more dominant role in the sovereign CDS market. Hence, our evidence on underreaction suggests that the sovereign CDS momentum is perhaps better described by the model in Barberis, Shleifer, and Vishny (1998). 
Since Jegadeesh and Titman (1993), there has been a vast literature on momentum, which is too large to be summarized in detail here, and has been surveyed in multiple studies (see, e.g., Asness et al 2014). The literature has examined momentum for a variety of markets, such as corporate bonds, loans, and CDSs (e.g., Jostova et al. (2013), Beyhaghi and Ehsani (2017), and Lee et al. (2014)), stock indices (e.g., Bhojraj and Swaminathan (2006) and Richards (1997)), futures markets (e.g., Asness et al. (2014) and Moskowitz et al. (2012)), currency markets (Menkhoff et al. (2012)), and sport betting markets (Moskowitz (2016)). Our paper complements this literature by analyzing a market where public information plays a dominant role and investors are primarily sophisticated financial institutions. Moreover, the momentum literature often focuses on micro-level information, our paper adds to this literature by focusing on macro information. The unique features of sovereign CDS momentum are that sovereign CDS momentum returns are positively skewed and higher during recessions. These features make it more challenging to attribute the momentum returns to arbitrageurs concerns of crash risk and exposures to business cycles.

The rest of the paper is organized as follows. Section II describes the data used in this study. The main analysis is presented in Section III, and Section IV concludes.

\section{Data}

In the sovereign CDS market, investors can purchase or sell protections against the default risk of sovereign governments. ${ }^{2}$ During the term of a sovereign CDS contract, the buyer makes quarterly payments, which are often referred to as CDS coupons or spreads, to the seller in exchange for the seller's promise of protection. The sovereign CDS spreads are paid on the 20th day of March, June, September and December. If a credit event occurs, the protection buyer will

\footnotetext{
${ }^{2}$ See Augustin et al (2018) for more details on the sovereign CDS market.
} 
be compensated by the loss at the credit event. Credit events include failure to pay, moratorium, obligation acceleration, and restructuring. The occurrence of a credit event is determined by the ISDA Credit Derivatives Determinations Committees. In most cases, sovereign CDSs are settled by cash with an auction process, in which the CDS seller makes a cash payment based on an auction-generated market price of certain eligible debt obligation of the sovereign government. An alternative is the "physical settlement", in which the protection buyers tender an eligible bond to the sellers and receive the par value of the bond. The market for sovereign CDS has been growing rapidly in the past decades. According to the Depository Trust \& Clearing Corporation, the aggregate notional amount of sovereign CDS contracts is around \$2 trillion in 2015, accounting for around $15 \%$ of all credit derivatives.

Our sovereign CDS data are from the Markit Group, which collects daily sovereign CDS quotation data from major CDS dealers to construct average CDS spreads. We focus on US dollar denominated CDS contracts with a five-year maturity and default tier being the senior unsecured debt, as these contracts are most widely traded and have the highest market liquidity. Our sample is from January 2001 to September 2015. There are 29 countries with active sovereign CDS contracts in our sample in 2001. This number has been increasing steadily and is 91 by 2015. In the appendix, we list all the countries in our sample, and the starting time of the sovereign CDS data for each country.

We follow Berndt and Obreja (2010) to construct the monthly sovereign "CDS returns." Specifically, the "return" of a CDS contract during a month is computed as the ratio of the markto-the-market profit/loss during the month to the notional amount, where the mark-to-the-market profit/loss is computed from the perspective of the protection seller, and is estimated based on 
the widely used ISDA CDS model. ${ }^{3}$ As pointed out in Berndt and Obreja (2010), this return effectively measures the sovereign CDS market implied excess returns from exposures to the underlying sovereign credit risk. As argued in Longstaff et al (2011), there are a number of advantages in using the sovereign CDS data to estimate sovereign credit spreads, relative to directly using sovereign debt data. Note that, according to this definition of sovereign CDS returns, as the underlying country's creditworthiness improves, its sovereign CDS returns increases. That is, a high sovereign CDS return is "good news" about the underlying country's creditworthiness.

We follow Xiao, Yan and Zhang (2018) to measure the monthly CDS returns based on the CDS spreads on the $20^{\text {th }}$ of a month and on the $19^{\text {th }}$ of the next month to make sure that the CDSs on these two dates have the same expiration date. Specifically, there are four coupon payment dates, the so-called IMM dates, each year: March 20, June 20, September 20 and December 20. All CDS contracts initiated between two IMM dates expire on the same day. After each IMM date, however, contracts with a new maturity date start trading. These new contracts are said to be "on-the-run" until the next IMM date. Our sovereign CDS data are based on onthe-run contracts. Hence, a contract on the $20^{\text {th }}$ of a month and a contract on the $19^{\text {th }}$ of the next month always expire on the same day. ${ }^{4}$

Table 1 provides summary statistics of our sovereign CDS data. The average CDS spread is 241 bps with a standard deviation of 556 bps. The monthly sovereign CDS return has a mean of $0.02 \%$ and a standard deviation of $2.59 \%$.

\footnotetext{
${ }^{3}$ See O'Kane (2008) for more details. To implement this valuation model, we assume a constant hazard rate and a $40 \%$ recovery rate, and use the LIBOR term structure as the discount rates.

${ }^{4}$ As a counter example, a contract on the 15th of a month and a contract on the 14th of the next month do not always have the same expiration date. For example, a contract on March 15 and a contract on April 14 have different expiration dates.
} 


\section{Empirical Results}

\section{A. Cross-sectional momentum}

We sort countries into 5 quintiles based on their past 3-month sovereign CDS returns. Quintile-1 countries have the highest returns, i.e., their credit worthiness improved the most according to the sovereign CDS market, while quintile-5 countries have the lowest sovereign CDS returns. Then, we form equal weighted portfolios of sovereign CDS contracts for each quintile. The portfolio returns during the first month after this sorting are reported in Panel A of Table 2.

The average return of the winner portfolio (quintile 1 ) is $0.26 \%$ per month, while that of the loser portfolio (quintile 5) is $-0.32 \%$ per month. That is, the winner portfolio, on average, outperforms the loser one by $0.58 \%$ per month, or $6.96 \%$ per year, with a $t$-statistic of 3.18 . Hence, our evidence suggests a strong momentum effect in the sovereign CDS market.

To account the risk factors in the existing literature, we regress the long-short strategy returns on a number of factors. The regression results are reported in Panel B of Table 2. For the regression in the first column, we include the market factor, which is constructed as the monthly equally-weighted sovereign CDS portfolio. The resulting alpha is $0.58 \%$ per month $(t=3.61)$ and is almost the same as the original average long-short return. In the second column, we also include the global value and momentum factors from Asness, Moskowitz and Pederson (2013), and the momentum alpha is $0.55 \%$ per month $(t=3.20)$ in this specification.

One might be concerned that the above momentum returns are driven mostly by CDS contracts that are on small economies and not actively traded. Without detailed data on the total size of the outstanding sovereign CDS contracts for each country, however, we form GDPweighted sovereign CDS portfolios to give lower weights to smaller economies. As shown in the 
third row of Panel A, the results based on GDP-weighted portfolios remain very similar. For example, the long-short portfolio return is $0.60 \%$ per month $(t=2.46)$. Moreover, we regress this GDP-weighted long-short strategy return on the previously mentioned factors. As shown in columns three and four of Panel B, the alpha is $0.61 \%$ per month $(t=2.75)$ when we account for the market factor, and is $0.50 \%$ per month $(t=2.33)$ when we also add the global value and momentum factors. Hence, the sovereign CDS momentum effect is not mostly driven by very small economies.

We conducted a number of subsample analyses. As shown in the first two rows of Panel C, the average momentum return is $0.54 \%(t=2.70)$ and $0.61 \%(t=2.16)$ in the first and second halves of our sample, respectively. We also split our sample according to the development status of the underlying countries. Specifically, we partition our sample into a subsample of developing economies and one for developed economies, based on the classification by the International Monetary Fund. ${ }^{5}$ As shown in the third and fourth rows, the average sovereign CDS momentum return is $0.41 \%(t=2.29)$ and $0.66 \%$ per month $(t=2.32)$ for the developed and developing economy subsamples, respectively.

The above analysis is based on a three-month sorting period and a one-month holding period. To examine the robustness of those results, we repeat the analysis by varying the sorting and holding periods. As shown in the first row of Panel D, where the holding period is one month, the momentum alpha remains similar when the sorting period varies from one to six months. When the holding period increases to six months, as shown in the first three rows, the magnitude of the momentum alpha decreases gradually, but remains statistically significant. When we further increase the holding period to 12 months, the alpha gradually decreases and becomes statistically insignificant.

\footnotetext{
${ }^{5}$ See, https://www.imf.org/external/pubs/ft/weo/2018/02/weodata/groups.htm.
} 


\section{$B$. Unique features of sovereign CDS momentum returns}

The sovereign CDS momentum returns appear unique relative to the momentum returns in other markets. First, sovereign CDS returns are positively skewed. As noted in and Daniel and Moskowitz (2016), the momentum strategy returns across many asset classes are subject to infrequent but significant crashes. They document momentum cashes in all the markets in their sample, which include four equity markets, index futures, commodity, fixed income, as well as currency. Chabot, Ghysels, and Jagannathan (2014) document momentum crashes during the pre-CRSP period for both the US and the UK stock markets. In contrast, the skewness of the momentum returns in our sample is $2.94(t=2.92)$. That is, this momentum strategy appears to have infrequent but large gains, rather than losses. Unlike the momentum strategies in other markets, the momentum strategy in the sovereign CDS market appears not exposed to crash risk in our sample.

Note that, during our sample period, there are a number of credit events, which lead to large negative sovereign CDS returns. One might be concerned that the previously reported mean and skewness of the sovereign CDS momentum strategy returns are mostly driven by those extreme returns. However, due to our large sample size, those observations have only small effects on the mean and skewness of sovereign CDS momentum returns. For example, we repeat our analysis after excluding those extreme returns in our sample. The resulting mean and skewness of sovereign CDS momentum returns remain similar.

Second, the sovereign CDS momentum strategy appears to perform better during recessions. Asness et al. (2014) find that momentum strategies tend to perform worse during recessions, especially for the strategies based on non-stock asset classes. Daniel and Moskowitz (2016) also find that momentum strategies tend to have poor performances during bad times. For 
example, momentum crashes tend occur in panic states, following market declines and when market volatility is high. To examine the cyclicality of the sovereign CDS momentum returns, we plot the cumulative return from the momentum strategy over time for strategies with various sorting periods in Figure 1. MOM $(6,1)$ refers to the cumulative return from the strategy with a six-month sorting period and a one-month holding period. MOM $(1,1)$ and MOM $(3,1)$ are defined similarly. The two shaded areas correspond to the NBER recessions in the U.S. The striking pattern of the figure is that the momentum strategy returns tend to increase significantly during the two recessions.

To test this more formally, we analyze the returns of these three strategies during the recession and non-recession sample periods. As shown in Panel E of Table 2, the average return for strategy $\operatorname{MOM}(3,1)$ is $1.43 \%$ during the two recessions, and is only $0.41 \%$ during the rest of our sample. The $t$-statistic for the difference between the two average returns is 2.24. Similarly, the momentum strategy outperforms during recessions for both $\operatorname{MOM}(1,1)$ and $\operatorname{MOM}(6,1)$. For example, the mean return for strategy $\operatorname{MOM}(6,1)$ is $1.71 \%$ and $0.25 \%$ per month during the recession and non-recession periods, respectively. The performance difference is $1.47 \%$ per month, with a $t$-statistic of 3.14 .

\section{Interpretation}

As summarized in Barberis and Thaler (2003), behavioral models of momentum can be classified by the two causes of momentum: initial underreaction followed by correction and initial overreaction followed by even more overreaction. If the momentum strategy return is due to overreaction, the alpha of the momentum trading strategy should revert back towards zero when the holding period is increased. On the other hand, if the momentum return is due to 
underreaction followed by correction, the alpha of the momentum strategy should increase with the holding period, and eventually stabilize.

To distinguish these two interpretations, we examine the alphas of the momentum strategy for longer holding periods. In particular, we compute the alphas the long-short strategies based on a three-month sorting period and various holding periods. As shown in Panel D of Table 2, the cumulative alpha during the holding period is $0.55 \%, 1.11 \%(=0.37 \% \times 3)$, and $1.50 \%$ $(=0.25 \% \times 6)$ if the holding period is 1,3 , and 6 months, respectively. The alpha gradually loses statistical significance when the holding period increases further. We plot this holding period cumulative alpha against the holding period in Figure 2, which shows that the holding period alpha increases with the holding period, and the increase slows down after 3 months. There is no sign of reversion back towards zero when we further increase the holding period, although the alpha becomes statistically insignificant when the holding period is longer than 9 months. This is

consistent with the underreaction interpretation that sovereign CDS market gradually incorporates information into prices and there is no evidence of overshooting.

\section{C.1. Timing of momentum profits}

What is the information that sovereign CDS market underreacts to? A natural candidate is perhaps the sovereign creditworthiness. The momentum strategy generates profits when this undereraction is eventually corrected. When should the correction happen, so that sovereign CDS spreads "catch up" with reality? A natural conjecture is perhaps when that sovereign credit information becomes public, i.e., when credit rating or outlook changes are publically announced. This conjecture implies that the sovereign CDS momentum strategy should be more profitable around the time when credit rating agencies, such as the Standard \& Poor's, announce changes in credit ratings or outlooks. 
To test this implication, we first construct an indicator variable $\mathrm{I}_{\mathrm{i}}$, which is 1 if country $i$ is in quintile 1 according to the sorting by sovereign CDS returns during months $t-2$ to $t$ (i.e., the sovereign CDS market indicates that the creditworthiness of country $i$ improved the most during the recent three months), is - 1 if country $i$ is in quintile 5 , and is 0 if country $i$ is in the other three quintiles.

The momentum effect implies that this indicator variable $\mathrm{I}_{\mathrm{i}, \mathrm{t}}$ should predict future sovereign CDS returns. We confirm this by regressing $\mathrm{r}_{\mathrm{i}, \mathrm{t}}$, the return of the sovereign CDS on country $i$ in month $t$, on $\mathrm{I}_{\mathrm{i}, \mathrm{t}-1}$, with country fixed effects and month fixed effects. As shown in the first column of Panel A of Table 3, the coefficient of $\mathrm{I}_{\mathrm{i}, \mathrm{t}-1}$ is $0.21(t=2.47)$. This estimate reflects the momentum effect analyzed previously: the monthly sovereign CDS returns of the countries in the top (bottom) quintile, which is sorted based on the previous 3 month CDS returns, is 21 basis points higher (lower) than that of the middle 3 quintiles.

We can now test the implication that the momentum strategy should be more profitable around the time when credit rating or outlook changes are announced. Specifically, we construct a dummy variable $D_{i t}$, which is 1 if there is a credit rating or outlook change on country $i$ in month $t$ by Standard \& Poor's, and 0 otherwise. We then regress $\mathrm{r}_{\mathrm{i}, \mathrm{t}}$, the return of the sovereign CDS on country $i$ in month $t$, on the interaction term between $\mathrm{I}_{\mathrm{it}-1}$ and $\mathrm{D}_{\mathrm{it}}$. Our prediction that sovereign CDS momentum strategy should be more profitable during announcement months implies that the coefficient of the interaction term should be positive.

Indeed, as shown in the second column of Panel A of Table 3, the coefficient of the interaction term $\mathrm{I}_{\mathrm{it}-1} \times \mathrm{D}_{\mathrm{it}}$ is $1.42(t=3.24)$. Note that the coefficient of $\mathrm{I}_{\mathrm{it}-1}$ is $0.10(t=1.31)$. Hence, the coefficient of the interaction term is more than 14 times the coefficient for $\mathrm{I}_{\mathrm{it}-1}$. That is, the predictive power of $\mathrm{I}_{\mathrm{it}-1}$ is more than 14 times stronger during announcement months than during 
other periods. When there is a public announcement of credit rating or outlook change, which has been partially anticipated by the sovereign CDS market, the creditworthiness information is more fully incorporated into prices. As a result, the sovereign CDS momentum profit is 14 times stronger during credit-event months than during other periods. This timing of the sovereign CDS momentum returns is consistent with the interpretation of under-reaction followed by correction.

\section{C.2. Long and short legs}

We separately analyze the profit from the long and short legs of the momentum strategy. Specifically, we construct two dummy variables I_Good ${ }_{i, t}$ and I_Bad ${ }_{i, t}$, where I_Good ${ }_{i, t}\left(I_{-}\right.$Bad $\left._{i, t}\right)$ is set to 1 if country $i$ is in quintile 1 (5) according to the sorting by sovereign CDS returns during months $t-2$ to $t$, and zero otherwise. We then regress $r_{i, t}$, the return of the sovereign CDS of country $i$ in month $t$, on I_Good ${ }_{\mathrm{i}, \mathrm{t}-1}$ and I_Bad $\mathrm{B}_{\mathrm{i}, \mathrm{t}-1}$, with country fixed effects and month fixed effects. As shown in the first column of Panel B of Table 3, the coefficient of I_Good ${ }_{i, t-1}$ is 0.24 $(t=2.38)$. That is, the sovereign CDSs of quintile- 1 countries outperform those of quintiles 2 through 4 by $0.24 \%$ per month. Similarly, the coefficient of I_Bad ${ }_{i, t-1}$, is $-0.18(t=1.78)$, which suggests that the sovereign CDSs of quintile-5 countries underperform those of quintiles 2 through 4 by $0.18 \%$ per month. That is, both the long and short legs of the strategy contribute to the momentum profits.

To further examine the timing of the momentum profits from the long and short legs, we include the interaction terms between these two dummy variables and the credit event dummy $\mathrm{D}_{\mathrm{it}}$. As shown in the second column of Panel B, the coefficient of I_Bad $\mathrm{Bat}_{\mathrm{t}-1}$, is $0.00(t=0.00)$, while that of the interaction term I_Bad ${ }_{i, t-1} \times D_{i t}$ is $-2.59(t=3.18)$. That is, the profit from the short leg is concentrated almost entirely during announcement months. In contrast, the coefficient of I_Good ${ }_{i, t-1}$ is $0.21(t=2.02)$, while the coefficient of I_Good ${ }_{i, t-1} \times D_{i t}$ is insignificant. That is, the 
profit from the long leg is distributed more evenly across time. In other words, while the underreaction to good news (i.e., upgrades in outlook or rating) tends to be corrected gradually over time, the underrection to bad news tends to be corrected more abruptly around the announcements.

As summarized in Barberis and Thaler (2003), there are two prominent models of momentum based on underreaction: Barberis, Shleifer, and Vishny (1998) and Hong and Stein (1999). The former is based on public information while the latter private information. The most important information in the sovereign CDS market is perhaps the information about macro variables, such as the credit worthiness of sovereign countries. Arguably most of the information in this market is public. Moreover, investors in this market are mostly sophisticated financial institutions. Hence, it is perhaps reasonable to expect most of them to be able to process the information. Therefore, our evidence suggests that the sovereign CDS momentum effect is perhaps better described by a public information based model, such as Barberis, Shleifer, and Vishny (1998).

\section{Global vs. local information}

Xiao, Yan, and Zhang (2018) find that sovereign CDS returns can predict future stock index returns, sovereign bond yields, as well real macroeconomic variables such as GDP and PMI. Interestingly, they find that the predictive power is almost entirely from the global, rather than country-specific, component of sovereign CDS returns. Motivated by these results, we decompose sovereign CDS returns into a global component and a country-specific component by a simple market model, and examine which component contributes to the momentum effect, i.e., has the predictive power for future sovereign CDS returns. 
The return decomposition is based on a 12-month rolling window regression of CDS returns on the market factor, which is constructed as the average sovereign CDS returns across all countries in our sample. For each sovereign CDs contract, we regress its return on the market factor. The regression residuals are classified as the country-specific component of sovereign CDS return. The remaining portion of the sovereign CDS returns is classified as the global component.

Which component has predictive power for future sovereign CDS returns? To analyze this, we first repeat our portfolio sorting analysis in Tables 2, using the two components as the sorting variables. That is, we first sort countries into 5 quintiles based on the global component of sovereign CDS returns. Quintile-1 countries have the highest global component of sovereign CDS returns in the previous three months, while quintile-5 countries have the lowest global component returns. We then form equal weighted portfolios of sovereign CDS contracts for each quintile. The portfolio returns during the first month after the sorting are reported in the first row of Panel A of Table 4. It shows that the quintile-1 portfolio outperforms the quintile-5 portfolio by $0.44 \%(t=2.64)$ per month. Similarly, we sort countries by the country-specific component of sovereign CDS returns. In this case, as shown in the second row, the quintile-1 portfolio outperforms the quintile- 5 one by $0.30 \%(t=2.00)$ per month. As a comparison, the last row reports the portfolio results when the sorting variable is the total sovereign CDS return for the same sample period as those for the previous two rows. In this case, the long-short return is $0.52 \%$ $(t=3.21)$ per month.

We also control for the same risk factors as those in Table 2. As shown in the last column of Panel A of Table 4, the resulting alphas are almost the same as the original long-short returns. 
Hence, our evidence suggests that both the global and the country-specific components of sovereign CDS returns can predict future CDS returns.

We further examine this predictability in panel regressions. Specifically, we extend the analysis in Panel A of Table 3 by replacing the indicator variable $\mathrm{I}_{\mathrm{i}, \mathrm{t}}$ by I_SYS $\mathrm{S}_{\mathrm{i}, \mathrm{t}}$ and I_IDIO $\mathrm{I}_{\mathrm{i}, \mathrm{t}}$. Similar to the definition of $\mathrm{I}_{\mathrm{i}, \mathrm{t}}, \mathrm{I}_{-} \mathrm{SYS}_{\mathrm{i}, \mathrm{t}}$ is 1 if country $i$ is in quintile 1 according to the sorting by the global component of sovereign CDS returns during months $t-2$ to $t$, is -1 if country $i$ is in quintile 5, and is 0 if country $i$ is in the other three quintiles. The indicator variable $\mathrm{I}_{-} \mathrm{IDIO}_{\mathrm{i}, \mathrm{t}}$ is based on the country-specific component of sovereign CDS returns, and is defined similarly.

To examine the marginal predictive power of I_SYS $i$ and I_IDIO ${ }_{i t}$, we regress $r_{i t}$, the return of the sovereign CDS on country $i$ in month $t$ on I_SYS $S_{\mathrm{i},-1-1}$ and I_IDIO $\mathrm{i}_{\mathrm{i}, \mathrm{-1}}$, with country fixed effects and month fixed effects. As shown in the first column of Panel B of Table 4, the coefficients of I_SYS $\mathrm{S}_{\mathrm{i}, \mathrm{t}-1}$ is $0.22(t=2.25)$, which reflects the marginal predictive power of the global component of sovereign CDS returns. Everything else being equal, the monthly sovereign CDS returns of the countries in the top (bottom) quintile, which is sorted based on the global component of sovereign CDS returns during the previous 3 months, is 22 basis point higher (lower) than that of the middle 3 quintiles. Similarly, the coefficient of $\mathrm{I}_{-} \mathrm{IDIO}_{\mathrm{i}, \mathrm{t}-1}$ is $0.14(t=2.25)$. Hence, both the global and country-specific components have marginal predictive power for future sovereign CDS returns, although the magnitude of the predictability of the countryspecific component is smaller.

Finally, we also include the interaction terms between credit event dummy $\mathrm{D}_{\mathrm{i}, \mathrm{t}}$ and the two indicator variables I_SYS $\mathrm{S}_{\mathrm{i}, \mathrm{t}-1}$ and I_IDIO $\mathrm{I}_{\mathrm{i}, \mathrm{t}-1}$. As shown in the second column of Panel B, the coefficient $\mathrm{I}_{-} \mathrm{IDIO}_{\mathrm{i}, \mathrm{t}-1} \times \mathrm{D}_{\mathrm{it}}$ is $1.42(t=3.30)$. Note that the coefficient of $\mathrm{I}_{-} \mathrm{IDIO}_{\mathrm{i}, \mathrm{t}-1}$ is 0.019 $(t=0.36)$. Hence, the profit from the long-short strategy based on the country-specific component 
of sovereign CDS returns is almost entirely concentrated around credit event months. That is, the underreaction to country-specific information is mostly corrected during announcement months. However, this is not the case for the long-short portfolio based on the global component. The coefficient of I_SYS $\mathrm{i}_{\mathrm{t}, \mathrm{t}-1} \times \mathrm{D}_{\mathrm{it}}$ is statistically insignificant. Hence, the profit from the long-short strategy based on the global component of sovereign CDS returns is more dispersed over time. In the other words, the correction to the underreaction to the global information is more gradual over time.

\section{E. Time series momentum}

Following Moskowitz et al. (2012), we also investigate the time series momentum, which is related to, but different from the above cross-sectional momentum. The cross-sectional momentum return is due to the fact that securities, which outperformed (underperformed) their peers recently, tend to continue outperforming (underperforming) their peers in the coming months. In contrast, the time-series momentum strategy is to buy securities with positive past returns and sell the securities with negative past returns. That is, the time series momentum strategy is constructed based on each security's own past returns, and there is no cross-sectional comparison across assets. Moskowitz et al. (2012) find that there is significant time series momentum returns in equity index, currency, commodity, and bond futures.

We sort countries into two groups based on their past 3-month sovereign CDS returns. Group 1 consists of countries with negative sovereign CDS returns during the previous 3 months while group 2 consists of countries with positive ones. Then, we form an equal-weighted portfolio that is long in sovereign CDSs on group-2 countries and short in those on group-1 countries. For the one-month holding period, as shown in the first row of Table 5, the average

return of this long-short strategy is $0.19 \%$ per month $(t=2.93)$. Although the time-series 
momentum strategy return is statistically significant, its magnitude is less than one third of that of the corresponding cross-sectional momentum strategy.

We repeat the above analysis by varying the sorting period from one to 12 months. As shown in the first row of Table 5, the time series momentum return remains significant when the sorting period is between one to nine months. We also vary the holding period from one to 12 months. As shown in Table 5, the average long-short strategy return is significantly positive when the holding period is up to 6 months, and gradually become statistically insignificant when we further increase the holding period.

\section{Conclusion}

This paper has documented a strong momentum effect in the sovereign CDS market. In contrast to the evidence in other financial markets, the sovereign CDS momentum returns are positively skewed, and higher during recessions. Hence, the sovereign CDS momentum returns cannot be attributed to momentum crash risk or the exposure to business cycles. Our evidence is consistent with the interpretation that the sovereign CDS momentum is due to investors' initial underreaction to public macro information followed by corrections, especially when there are public announcements on credit rating or outlook changes. 


\section{References}

Asness, Cliff, Tobias Moskowitz, and Lasse Pedersen, 2013, Value and Momentum Everywhere, Journal of Finance 68, 929-985.

Asness, Cliff, Andrea Frazzini, Ronen Israel, and Tobias Moskowitz, 2014, Fact, Friction and Momentum Investing, Journal of Portfolio Management 40, 75-92.

Augustin, Patrick, Valeri Sokolovski, Marti Subrahmanyam and Davide Tomio, 2018, Why Do Investor Buy Sovereign Default Insurance? working paper.

Barberis, Nicholas, Andrei Shleifer, and Robert Vishny, 1998, A Model of Investor Sentiment, Journal of Financial Economics 49, 307-343.

Barberis, Nicholas and Richard Thaler, 2013, A Survey of Behavioral Finance, in Constantinides, G., Harris, M., Stulz, R. (Eds.), Handbook of the Economics of Finance, North Holland, Amsterdam.

Berndt, Antje, and Iulian Obreja, 2010, Decomposing European CDS returns, Review of Finance $14,189-233$.

Beyhaghi, Mehdi and Sina Ehsani, 2017, The cross-section of expected returns in the secondary corporate loan market, Review of Asset Pricing Studies 7, 243-277.

Bhojraj, Sanjeev and Bhaskaran Swaminathan, 2006, Macromomentum: Returns predictability in international equity indices, Journal of Business 79, 429-451.

Chabot, Benjamin, Eric Ghysels, and Ravi Jagannathan, 2014, Momentum trading, return chasing and predictable crashes, working paper.

Daniel, Kent, David Hirshleifer, and Avanidhar Subrahmanyam, 1998, Investor Psychology and Security Market Under-and Overreactions, Journal of Finance 53, 1839-1885.

Daniel, Kent and Moskowitz, Tobias J, 2016, Momentum Crashes, Journal of Financial Economics 122, 221-247. 
De Long, Bradford, Andrei Shleifer, Lawrence Summers and Robert Waldmann, 1990, Positive feedback investment strategies and destabilizing rational speculation, Journal of Finance 45, 375-395.

French, Kenneth, 2008, Presidential address: The cost of active investing, Journal of Finance 63, 1537-1573.

Hong, Harrison and Jeremy Stein, 1999, A Unified Theory of Underreaction, Momentum Trading, and Overreaction in Asset Markets, Journal of Finance 54, 2143-2184.

Jegadeesh, Narasimhan and Sheridan Titman, 1993, Returns to Buying Winners and Selling Losers: Implications for Stock Market Efficiency, Journal of Finance 48, 65-91.

Jostova Gergana, Stanislava Nikolova, Alexander Philipov, and Christof Stahel, 2013, Momentum in corporate bond returns, Review of Financial Studies 26, 1649-1693.

Lee, Jongsub, Andy Naranjo, and Stace Sirmans, 2014, CDS Momentum: Slow Moving Credit Ratings and Cross-Market Spillovers, working paper.

Longstaff, Francis, Jun Pan, Lasse Pedersen, and Kenneth Singleton, 2011, How Sovereign is Sovereign Credit Risk? American Economic Journal: Macroeconomics 3, 75-103.

Menkhoff, Lukas, Lucio Sarno, Maik Schmeling, and Andreas Schrimpf, 2012, Currency Momentum Strategies, Journal of Financial Economics 106, 660-684.

Moskowitz, Tobias, Yao Hua Ooi, and Lasse Pedersen, 2012, Time Series Momentum, Journal of Financial Economics 104, 228-250.

Moskowitz, Tobias, 2017, Asset Pricing and Sports Betting, working paper.

O’Kane, Dominic, 2008, Modelling Single-name and Multi-name Credit Derivatives (John Wiley \& Sons).

Pan, Jun, and Kenneth Singleton, 2008, Default and Recovery Implicit in the Term Structure of Sovereign CDS Spreads, Journal of Finance, 63, 2345-2384. 
Richards, Anthony, 1997, Winner-Loser Reversal in National Stock Market Indices: Can They Be Explained? Journal of Finance, 52, 2129-2144.

Rouwenhorst, Geert, 1998, International Momentum Strategies, Journal of Finance 53, 267-284.

Xiao, Yaqing, Hongjun Yan and Jinfan Zhang, 2018, Global Perspective or Local Knowledge: The Macro-information in the Sovereign CDS Market, working paper. 


\section{Table 1. Summary statistics}

This table reports the summary statistics of CDS spread and CDS return. CDS spread is the daily sovereign CDS spread, and is from Markit. CDS return is computed from the CDS spreads on the $20^{\text {th }}$ of a month and on the $19^{\text {th }}$ of the next month. The monthly sovereign CDS return is computed as the ratio of the mark-to-the-market profit/loss during the month to the notional amount, where the mark-to-the-market profit/loss is computed from the perspective of the protection seller, and is estimated based on the ISDA CDS model, where the hazard rate is a constant and the recovery rate is $40 \%$, and the discount rates are from the LIBOR term structure.

\begin{tabular}{lcccccccc}
\hline & Mean & Std Dev & 1st & 25th & 50th & 75th & 99th & N \\
\hline CDS spread (bps) & 240.56 & 555.71 & 1.74 & 36.66 & 119.28 & 276.43 & 1960.15 & 12193 \\
CDS return (\%) & 0.02 & 2.59 & -7.83 & -0.22 & 0.01 & 0.37 & 6.64 & 12065 \\
\hline
\end{tabular}




\section{Table 2. Cross-sectional Momentum}

Countries are sorted into 5 quintiles based on their past 3-month sovereign CDS returns. Quintile 1 (5) countries have the highest (lowest) CDS returns, i.e., their credit worthiness improved (deteriorated) the most. Then, for each quintile, we form an equal weighted or GDP weighted portfolio of sovereign CDSs and compute its return for the next month. Panel A reports the average return of each quintile portfolio, and the long-short portfolio that is long in quintile 1 and short in quintile 5. Panel B reports the results from the regression of the monthly returns of the long-short portfolios on various factors. MKT is the monthly return of the equal-weighted portfolio of all sovereign CDSs. VAL and MOM are the global value and momentum factors in Asness, Moskowitz and Pederson (2013), and are obtained from the AQR data library. Panel C reports the portfolio results based on subsamples. The first and send rows are based on the sample period 2001 through 2007, and 2008 through 2015, respectively. The third and fourth rows are based on, respectively, the subsamples of developed and developing economies, which are defined by the IMF. Panel D reports the results based on various sorting and holding periods. Panel E reports the average return of the long-short portfolio during the NBER-recession and non-recession periods. $\operatorname{MOM}(n, h)$ refers to the portfolio with a $n$-month sorting period and $h$-month holding period. The $t$ statistics for skewness are based on bootstrapped standard errors. All other $t$-statistics are based on standard errors that are Newey-West (1987) adjusted with 12 lags. All t-statistics are reported in parentheses. ${ }^{* *},{ }^{* *}$, and $*$ indicate significance levels of $1 \%, 5 \%$, and $10 \%$, respectively.

Panel A. Momentum returns in the sovereign CDS market

\begin{tabular}{llcccccc}
\hline & & $\begin{array}{c}\text { P1 } \\
\text { (high) }\end{array}$ & P2 & P3 & P4 & $\begin{array}{c}\text { P5 } \\
\text { (low) }\end{array}$ & P1-P5 \\
\hline Equal weight & Mean (\%) & $0.26^{*}$ & 0.08 & -0.00 & -0.00 & -0.32 & $0.58^{* * *}$ \\
& & $(1.88)$ & $(1.04)$ & $(-0.03)$ & $(0.02)$ & $(1.42)$ & $(3.18)$ \\
& Skewness & $1.61^{* *}$ & 0.38 & -1.87 & -1.64 & $-3.21^{* *}$ & $2.94^{* * *}$ \\
& & $(2.04)$ & $(-0.82)$ & $(-1.87)$ & $(-0.90)$ & $(-2.69)$ & $(2.92)$ \\
\hline GDP weight & Mean (\%) & 0.18 & 0.05 & 0.02 & 0.02 & $-0.42^{*}$ & $0.60^{* *}$ \\
& & $(1.17)$ & $(0.85)$ & $(0.46)$ & $(0.31)$ & $(1.70)$ & $(2.46)$ \\
& \multirow{2}{*}{ Skewness } & 0.09 & 0.13 & 0.73 & 1.98 & $4.47^{* *}$ & $3.30^{*}$ \\
& & $(0.22)$ & $(0.29)$ & $(0.92)$ & $(0.84)$ & $(2.33)$ & $(1.92)$ \\
\hline
\end{tabular}


Panel B. Sovereign CDS momentum alphas (\%)

\begin{tabular}{lcccc}
\hline & $\begin{array}{c}\text { Equal-weighted } \\
\text { Returns }\end{array}$ & $\begin{array}{c}\text { Equal-weighted } \\
\text { Returns }\end{array}$ & $\begin{array}{c}\text { GDP-Weighted } \\
\text { Returns }\end{array}$ & $\begin{array}{c}\text { GDP-Weighted } \\
\text { Returns }\end{array}$ \\
\hline Alpha & $0.58^{* * *}$ & $0.55^{* * *}$ & $0.61^{* * *}$ & $0.50^{* *}$ \\
& $(3.61)$ & $(3.20)$ & $(2.75)$ & $(2.33)$ \\
MKT & $-0.83^{*}$ & $0.89^{* *}$ & $1.21^{*}$ & $1.31^{* *}$ \\
& $(1.90)$ & $(2.11)$ & $(1.91)$ & $(2.25)$ \\
VAL & & 0.25 & & $0.56^{* *}$ \\
MOM & & $(1.39)$ & & $(2.05)$ \\
& & -0.01 & & 0.07 \\
Observations & & $(0.08)$ & & $(0.42)$ \\
R-Square & 175 & 175 & 175 & 175 \\
\hline
\end{tabular}

Panel C. Sovereign CDS momentum returns in subsamples (\%)

\begin{tabular}{lcccccc}
\hline & $\begin{array}{c}\text { P1 } \\
\text { (high) }\end{array}$ & P2 & P3 & P4 & $\begin{array}{c}\text { P5 } \\
\text { (low) }\end{array}$ & P1-P5 \\
\hline $2001-2007$ & $0.30^{*}$ & 0.11 & 0.00 & -0.00 & -0.23 & $0.54^{* *}$ \\
& $(1.85)$ & $(1.50)$ & $(0.18)$ & $(-0.21)$ & $(-0.80)$ & $(2.54)$ \\
$2008-2015$ & 0.22 & 0.05 & 0.00 & 0.00 & -0.39 & $0.61^{* *}$ \\
& $(1.05)$ & $(0.38)$ & $(-0.07)$ & $(-0.05)$ & $(-1.20)$ & $(2.16)$ \\
\hline Developed & 0.11 & 0.02 & -0.00 & 0.01 & -0.29 & $0.41^{* *}$ \\
& $(1.40)$ & $(0.45)$ & $(-0.02)$ & $(0.31)$ & $(-1.45)$ & $(2.29)$ \\
Developing & 0.32 & 0.06 & 0.07 & 0.05 & -0.35 & $0.66^{* *}$ \\
& $(1.53)$ & $(0.68)$ & $(0.81)$ & $(0.47)$ & $(-1.08)$ & $(2.32)$ \\
\hline
\end{tabular}

Panel D. Momentum alphas (\%): n-month sorting period, h-month holding period

\begin{tabular}{llll}
\hline \multirow{3}{*}{$h=1$} & $n=1$ & $n=3$ & $n=6$ \\
\cline { 2 - 4 }$h=3$ & $0.46^{* * *}$ & $0.55^{* * *}$ & $0.45^{* * *}$ \\
& $(2.67)$ & $(3.20)$ & $(2.81)$ \\
$h=6$ & $0.39^{* * *}$ & $0.37^{* * *}$ & $0.38^{* * *}$ \\
& $(3.67)$ & $(3.04)$ & $(3.28)$ \\
$h=9$ & $0.26^{* * *}$ & $0.25^{* *}$ & $0.20^{*}$ \\
& $(3.15)$ & $(2.47)$ & $(1.82)$ \\
$h=12$ & $0.12^{*}$ & $0.15^{*}$ & 0.11 \\
& $(1.85)$ & $(1.68)$ & $(1.06)$ \\
& 0.08 & 0.13 & 0.13 \\
& $(1.17)$ & $(1.61)$ & $(1.32)$ \\
\hline
\end{tabular}


Panel E. Momentum returns through business cycles (\%)

\begin{tabular}{lccc}
\hline & Recession & Non-recession & Difference \\
\hline $\operatorname{MOM}(1,1)$ & 1.38 & 0.31 & $1.07^{* *}$ \\
& & & $(2.37)$ \\
$\operatorname{MOM}(3,1)$ & 1.43 & 0.41 & $1.02^{* *}$ \\
& & & $(2.24)$ \\
$\operatorname{MOM}(6,1)$ & 1.71 & 0.25 & $1.47^{* * *}$ \\
& & & $(3.14)$ \\
\hline
\end{tabular}




\section{Table 3. The timing of predictability}

This table reports results from panel regressions. The dependent variable is $r_{i, t}$, the sovereign CDS return of country $i$ in month $t$. $\mathrm{I}_{\mathrm{i}, \mathrm{t}-1}$ is 1 , if country $i$ is in quintile 1 according to the sorting based on sovereign CDS returns during months $t-3$ to $t-1$; is -1 if country $i$ is in quintile 5 , and is 0 if country $i$ is in the other three quintiles. $D_{i, t}$ is 1 if Standard \& Poor's announced a credit rating change or outlook change for country $i$ in month $t$, and 0 otherwise. I_Good $\mathrm{i}_{\mathrm{i}, \mathrm{t}-1}\left(\mathrm{I}_{-} \mathrm{Bad}_{\mathrm{i}, \mathrm{t}-1}\right)$ is 1 , if country $i$ is in quintile 1 (5) according to the sorting based on sovereign CDS returns during months $t-3$ to $t-1$, and 0 otherwise. T-statistics, in parentheses, are based on standard errors that are clustered by month. ${ }^{* * *}, * *$, and * indicate significance levels of $1 \%, 5 \%$, and $10 \%$, respectively.

Panel A: Timing of predictability

\begin{tabular}{lcc}
\hline & Return (\%) & Return (\%) \\
\cline { 2 - 3 } $\mathrm{I}_{\mathrm{i}, \mathrm{t}-\mathrm{1}}$ & $0.21^{* *}$ & 0.10 \\
& $(2.47)$ & $(1.31)$ \\
$\mathrm{I}_{\mathrm{i}, \mathrm{t}-\mathrm{f}} \times \mathrm{D}_{\mathrm{i}, \mathrm{t}}$ & & $1.42^{* * *}$ \\
& & $(3.24)$ \\
$\mathrm{D}_{\mathrm{i}, \mathrm{t}}$ & & $-0.77^{* * *}$ \\
& & $(2.97)$ \\
& & \\
Country Fixed Effects & & Yes \\
Month Fixed Effects & Yes & Yes \\
Observations & Yes & 10,168 \\
R-squared & 10,168 & 0.13 \\
\hline
\end{tabular}


Panel B: Good vs. bad news

\begin{tabular}{lcc}
\hline & Return (\%) & Return (\%) \\
\cline { 2 - 3 } I_Good $_{\mathrm{i}, \mathrm{t}-1}$ & $0.24^{* *}$ & $0.21^{* *}$ \\
& $(2.38)$ & $(2.02)$ \\
I_Good $_{\mathrm{i}, \mathrm{t}-\mathrm{1}} \times \mathrm{D}_{\mathrm{i}, \mathrm{t}}$ & & 0.23 \\
& & $(0.58)$ \\
I_Bad & & 0.00 \\
$\mathrm{i}, \mathrm{t}-\mathrm{t}$ & $-0.18^{*}$ & $(0.00)$ \\
I_Bad $_{\mathrm{i}, \mathrm{t}-1} \times \mathrm{D}_{\mathrm{i}, \mathrm{t}}$ & $(1.78)$ & $-2.59^{* * *}$ \\
& & $(3.18)$ \\
$\mathrm{D}_{\mathrm{i}, \mathrm{t}}$ & & -0.17 \\
& & $(1.08)$ \\
Country Fixed Effects $_{\text {Month Fixed Effects }}$ & & \\
Observations & Yes & Yes \\
R-squared & 10,168 & Yes \\
\hline
\end{tabular}




\section{Table 4. Global vs. Country-specific}

Panel A reports the returns of portfolios, which are sorted based on the global component of sovereign CDS returns (row 1), the country-specific component (row 2), and the total return (row 3). The CDS return decomposition is based on a 12-month rolling window regression of CDS returns on the average CDS returns across all countries in our sample. The regression residual is the country-specific component and the remaining portion of the CDS return is the global component. Since we need 12-month data to estimate the regressions, the sample period of the portfolio returns is January 2002 to September 2015. Countries are sorted into 5 quintiles. Quintile 1 (5) countries have highest (lowest) returns. Then, for each quintile, we form an equal weighted portfolio of sovereign CDSs and compute its return for the next month. Panel A reports the average return for each of the portfolios, and for the long-short portfolio that is long in quintile 1 and short in quintile 5. The "alpha” column reports the alpha of the long-short strategy after adjusting for MKT, VAL, and MOM, all of which are defined in Table 2. T-statistics are based on standard errors that are Newey-West (1987) adjusted with 12 lags, and are reported in parentheses. Panel $B$ reports estimates of panel regressions. The dependent variable is $r_{i, t}$, the return of the sovereign CDS of country $i$ in month $t$. I_Global $\mathrm{i}_{\mathrm{i}-\mathrm{-}-1}$ is 1 , if country $i$ is in quintile 1 according to the sorting based on the global component sovereign CDS returns during months $t-3$ to $t-1$, is set to -1 if country $i$ is in quintile 5 , and is set to 0 if country $i$ is in the other three quintiles. I_Country $y_{i, t-1}$ is defined similarly based on the country-specific component. $\mathrm{D}_{\mathrm{i}, \mathrm{t}}$ is 1 if Standard \& Poor's announced a credit rating change or outlook change for country $i$ in month $t$, and 0 otherwise. T-statistics, in parentheses, are based on standard errors that are clustered by month. ${ }^{* *},{ }^{* *}$, and $*$ indicate significance levels of $1 \%, 5 \%$, and $10 \%$, respectively.

Panel A: Portfolio returns (\%)

\begin{tabular}{lccccccc}
\hline Sorting variable & $\begin{array}{c}\text { P1 } \\
\text { (high) }\end{array}$ & P2 & P3 & P4 & $\begin{array}{c}\text { P5 } \\
\text { (low) }\end{array}$ & P1-P5 & alpha \\
\hline Global & 0.25 & 0.09 & 0.01 & -0.03 & -0.19 & $0.44 * * *$ & $0.44^{* * *}$ \\
& $(1.63)$ & $(0.95)$ & $(0.18)$ & $(-0.48)$ & $(-0.94)$ & $(2.64)$ & $(2.65)$ \\
Country-specific & 0.19 & 0.02 & 0.00 & 0.05 & -0.12 & $0.30^{* *}$ & $0.30^{* *}$ \\
& $(1.08)$ & $(0.27)$ & $(0.07)$ & $(0.73)$ & $(-0.53)$ & $(2.00)$ & $(2.06)$ \\
Total & $0.25^{*}$ & 0.06 & 0.01 & -0.00 & -0.27 & $0.52 * * *$ & $0.52^{* * *}$ \\
& $(1.94)$ & $(0.82)$ & $(0.11)$ & $(-0.01)$ & $(-1.37)$ & $(3.21)$ & $(3.25)$ \\
\hline
\end{tabular}


Panel B: Sovereign CDS return (\%)

\begin{tabular}{lcc}
\hline & Return & Return \\
\cline { 2 - 3 } I_Global $_{\mathrm{i}, \mathrm{t}-1}$ & $0.22^{* *}$ & $0.16^{*}$ \\
& $(2.25)$ & $(1.84)$ \\
I_Country $_{\mathrm{i}, \mathrm{t}-1}$ & $0.14^{* *}$ & 0.02 \\
& $(2.25)$ & $(0.36)$ \\
I_Global $_{\mathrm{i}, \mathrm{t}-1} \times \mathrm{D}_{\mathrm{i}, \mathrm{t}}$ & & 0.64 \\
& & $(1.31)$ \\
I_Country $_{\mathrm{i}, \mathrm{t}-1} \times \mathrm{D}_{\mathrm{i}, \mathrm{t}}$ & & $1.42^{* * *}$ \\
& & $(3.30)$ \\
$\mathrm{D}_{\mathrm{i}, \mathrm{t}}$ & & $0.58^{* *}$ \\
& & $(2.46)$ \\
Country Fixed Effects & & \\
Month Fixed Effects & Yes & Yes \\
Observations & Yes & Yes \\
R-squared & 9,892 & 9,892 \\
\hline
\end{tabular}




\section{Table 5. Time-series Momentum}

Countries are sorted into two groups based on their past $n$-month sovereign CDS returns. Group 1 consists of countries with negative sovereign CDS returns while group 2 consists of countries with positive ones. Then, we form an equal-weighted portfolio that is long in sovereign CDSs on group-2 countries and short in those on group- 1 countries. These portfolios are held for $h$ months before rebalancing. This table reports average monthly returns from this time series momentum strategy. T-statistics are based on standard errors that are Newey-West (1987) adjusted with 12 lags, and are reported in parentheses. ***, $* *$, and $*$ indicate significance levels of $1 \%, 5 \%$, and $10 \%$, respectively.

Time series momentum returns (\%)

\begin{tabular}{cccccc}
\hline \multirow{4}{*}{$h=1$} & $n=1$ & $n=3$ & $n=6$ & $n=9$ & $n=12$ \\
\cline { 2 - 6 }$h=3$ & $0.20^{* *}$ & $0.19^{* * *}$ & $0.23^{* * *}$ & $0.13^{* *}$ & 0.08 \\
& $(2.53)$ & $(2.93)$ & $(2.66)$ & $(2.22)$ & $(1.33)$ \\
& $0.15^{* * *}$ & $0.11^{* *}$ & $0.10^{* * *}$ & 0.09 & 0.06 \\
$h=6$ & $(3.12)$ & $(2.26)$ & $(2.61)$ & $(1.49)$ & $(1.02)$ \\
& $0.07^{* * *}$ & $0.06^{*}$ & 0.06 & 0.05 & 0.04 \\
& $(2.93)$ & $(1.88)$ & $(1.29)$ & $(0.82)$ & $(0.56)$ \\
$h=9$ & $0.04^{*}$ & 0.04 & 0.04 & 0.03 & 0.03 \\
& $(1.69)$ & $(1.30)$ & $(0.99)$ & $(0.58)$ & $(0.40)$ \\
$h=12$ & 0.03 & 0.04 & 0.04 & 0.03 & 0.02 \\
& $(1.50)$ & $(1.41)$ & $(0.91)$ & $(0.44)$ & $(0.25)$ \\
\hline
\end{tabular}




\section{Figure 1. Cumulative monthly returns during recession}

This figure plots cumulative returns from three cross-sectional momentum strategies. $\mathrm{MOM}(6,1)$ is the strategy with a 6-month sorting period and a 1-month holding period. $\operatorname{MOM}(3,1)$ and $\operatorname{MOM}(1,1)$ are defined similarly. Details of the strategies are described in Table 2. Shaded areas correspond to two NBER recessions from March 2001 to November 2001 and from December 2007 to June 2009.

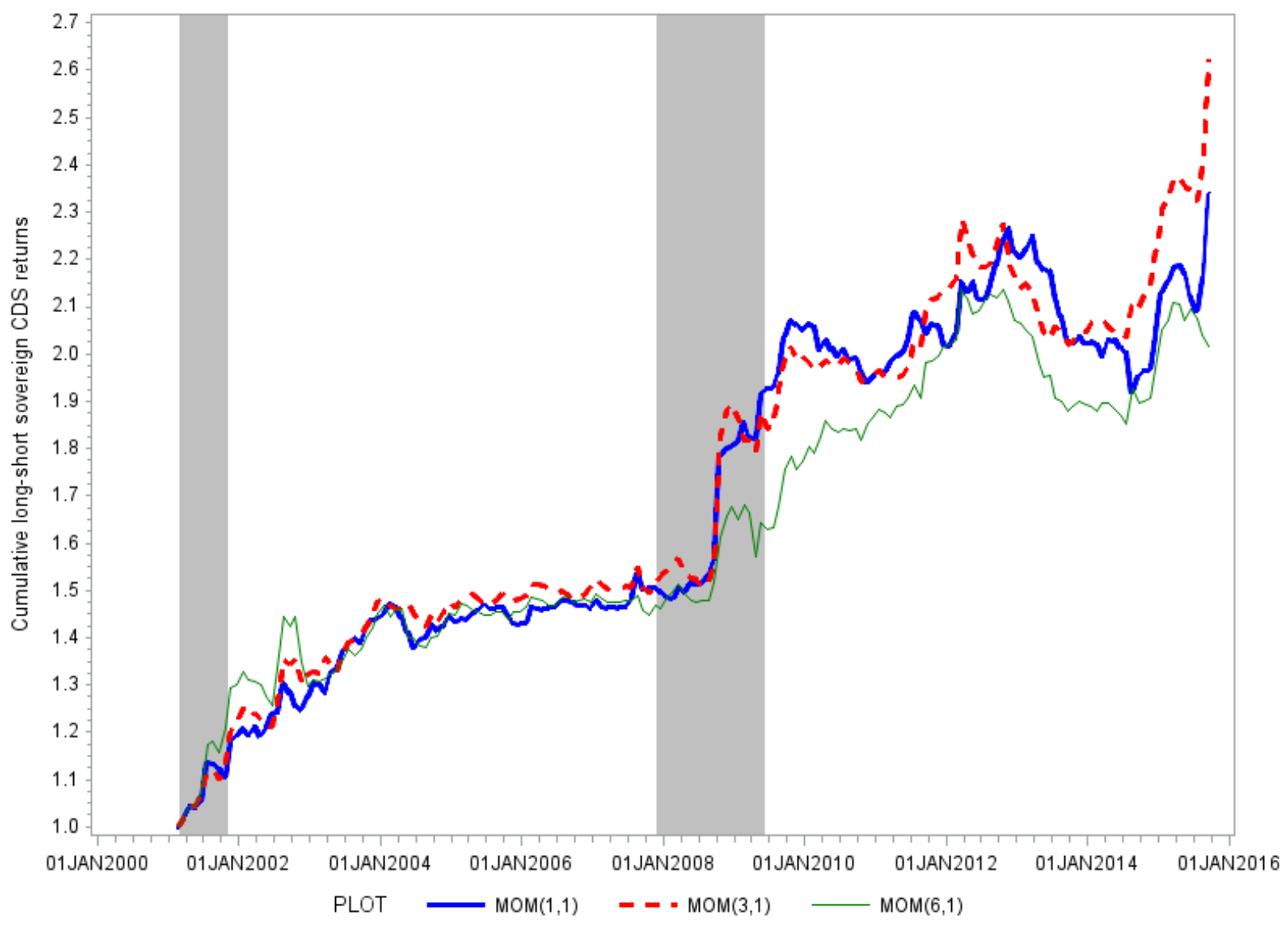




\section{Figure 2. Sovereign CDS momentum alphas}

The figure plots the alpha cumulated during the holding period of the sovereign CDS momentum strategy, described in Table 2, against the holding period. All strategies have a 3-month sorting period. All alphas are after controlling for MKT, VAL, and MOM, all of which are defined in Table 2.

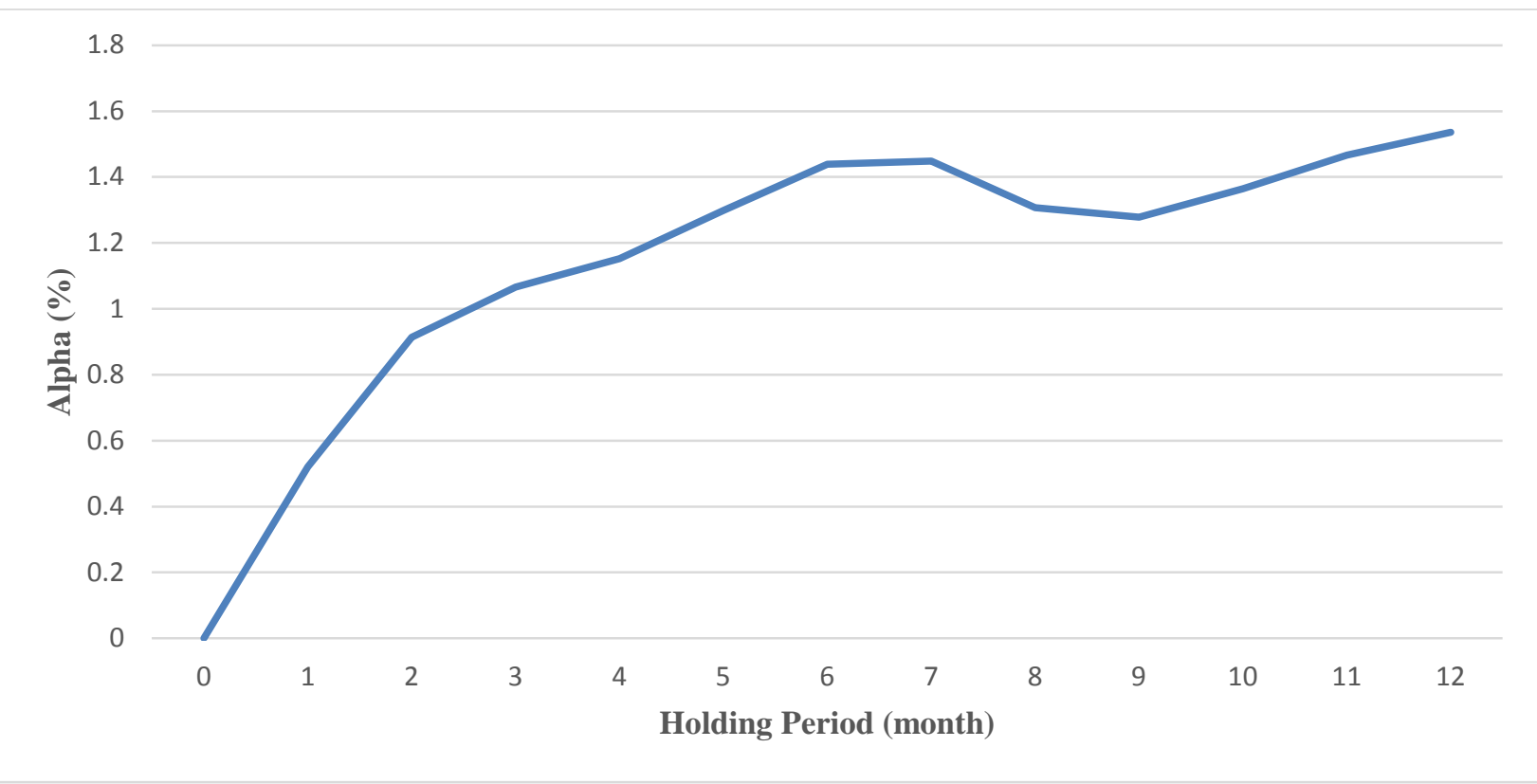


Appendix: The list of countries with sovereign CDS contracts

\begin{tabular}{|c|c|c|c|}
\hline Country & Starting time of CDS data & Country & Starting time of CDS data \\
\hline Algeria & Sep-2008 & Lebanon & Apr-2003 \\
\hline Angola & Oct-2009 & Lithuania & May-2002 \\
\hline Argentina & Apr-2001 & Malaysia & May-2001 \\
\hline Austria & Jul-2001 & Malta & Aug-2004 \\
\hline Australia & Oct-2003 & Macedonia & Oct-2011 \\
\hline Barbados & Jul-2006 & Mexico & Feb-2001 \\
\hline Belgium & Mar-2001 & Morocco & May-2001 \\
\hline Bulgaria & May-2001 & Netherlands & Sep-2003 \\
\hline Bahrain & Aug-2004 & Nigeria & Jan-2007 \\
\hline Belize & Jan-2010 & Norway & Nov-2003 \\
\hline Brazil & Feb-2001 & New Zealand & Jan-2004 \\
\hline Tunisia & Dec-2003 & Oman & Dec-2008 \\
\hline Canada & Oct-2003 & Pakistan & Aug-2004 \\
\hline Chile & Mar-2002 & Panama & Mar-2002 \\
\hline China & Feb-2001 & Peru & Mar-2002 \\
\hline Hong Kong & Sep-2004 & Philippines & Apr-2001 \\
\hline Colombia & Apr-2001 & Poland & Feb-2001 \\
\hline Costa Rica & Sep-2003 & Portugal & Mar-2002 \\
\hline Croatia & Feb-2001 & Qatar & Oct-2001 \\
\hline Cyprus & Aug-2002 & Hungary & Apr-2001 \\
\hline Czech & Apr-2001 & Georgia & Jul-2015 \\
\hline Germany & Nov-2002 & Romania & Apr-2002 \\
\hline Denmark & Dec-2002 & Ghana & Jun-2008 \\
\hline Dominica & Aug-2003 & Russia & Oct-2001 \\
\hline Ecuador & Jul-2003 & Saudi Arabia & Mar-2007 \\
\hline Egypt & Apr-2002 & Singapore & Aug-2003 \\
\hline El Salvador & Jul-2003 & Slovakia & Jun-2001 \\
\hline Estonia & Jul-2004 & Slovenia & Mar-2002 \\
\hline Fiji & Jul-2007 & South Africa & Feb-2001 \\
\hline Finland & Aug-2002 & Spain & Mar-2001 \\
\hline France & May-2002 & Serbia & Jul-2006 \\
\hline Greece & Feb-2001 & Sri Lanka & Jan-2008 \\
\hline Guatemala & Sep-2003 & Sweden & Jul-2001 \\
\hline Iceland & Apr-2004 & Switzerland & Jul-2007 \\
\hline India & Aug-2003 & Taiwan & Sep-2006 \\
\hline Indonesia & Jan-2002 & Thailand & Apr-2001 \\
\hline Iraq & Mar-2006 & Trinidad and Tobago & Dec-2004 \\
\hline Ireland & Feb-2003 & Turkey & Feb-2001 \\
\hline Israel & May-2001 & UAE & Mar-2007 \\
\hline Italy & Mar-2001 & United Kingdom & Apr-2006 \\
\hline Jamaica & Oct-2003 & Ukraine & Oct-2002 \\
\hline Japan & Feb-2001 & Uruguay & Jun-2002 \\
\hline Jordan & Oct-2003 & US & Jan-2004 \\
\hline Kazakhstan & Feb-2004 & Venezuela & Mar-2001 \\
\hline $\begin{array}{l}\text { South Korea } \\
\text { Latvia }\end{array}$ & $\begin{array}{l}\text { May-2001 } \\
\text { Sep-2004 }\end{array}$ & Vietnam & Sep-2002 \\
\hline
\end{tabular}

